\title{
Neutrophil-induced Injury of Rat Pulmonary Alveolar Epithelial Cells
}

\author{
Richard H. Simon, Peter D. DeHart, and Robert F. Todd III \\ Pulmonary \& Critical Care Medicine Division, and the Hematology and Oncology Division, Department of Internal Medicine, \\ University of Michigan School of Medicine, Ann Arbor, Michigan 48109
}

\begin{abstract}
The damage to pulmonary alveolar epithelial cells that occurs in many inflammatory conditions is thought to be caused in part by phagocytic neutrophils. To investigate this process, we exposed monolayers of purified rat alveolar epithelial cells to stimulated human neutrophils and measured cytotoxicity using a ${ }^{51} \mathrm{Cr}$ release assay. We found that stimulated neutrophils killed epithelial cells by a process that did not require neutrophil-generated reactive oxygen metabolites. Pretreatment of neutrophils with an antibody (anti-Mo1) that reduced neutrophil adherence to epithelial cells limited killing. Although a variety of serine protease inhibitors partially inhibited cytotoxicity, we found that neutrophil cytoplasts, neutrophil lysates, neutrophil-conditioned medium, purified azurophilic or specific granule contents, and purified human neutrophil elastase did not duplicate the injury. We conclude that stimulated neutrophils can kill alveolar epithelial cells in an oxygen metabolite-independent manner. Tight adherence of stimulated neutrophils to epithelial cell monolayers appears to promote epithelial cell killing.
\end{abstract}

\section{Introduction}

Injury to alveolar epithelial cells is a prominent feature in a variety of lung diseases. In the adult respiratory distress syndrome, destruction of alveolar epithelial cells has been noted to be a frequent and early finding $(1,2)$. Loss of the permeability barrier formed by alveolar lining cells is likely to be an important factor contributing to the alveolar flooding which occurs in this condition (3). Although the precise mechanisms of lung injury in the adult respiratory distress syndrome remain to be defined, many investigators have suggested that stimulated neutrophils are an important cause of lung damage in at least some cases of the disease (4-13).

To elucidate one potentially important mechanism of injury, we studied the cytotoxic effect of stimulated human neutrophils upon isolated rat alveolar epithelial cells. Using an in vitro cytotoxicity assay, we found that stimulated neutrophils kill epithelial cells in a manner that appears to require intimate neutrophil-epithelial cell contact but does not involve neutrophilgenerated oxygen metabolites.

\section{Methods}

Materials. Elastase (type I), trypsin (type III), soybean trypsin inhibitor (type II-S), deoxyribonuclease I (type III), bovine serum albumin (A6003),

Address reprint requests to Dr. Simon, Pulmonary \& Critical Care Medicine Division, 3916 Taubman Center, Ann Arbor, MI 48109. 1986.

Received for publication 21 January 1986 and in revised form 7 July

J. Clin. Invest.

(C) The American Society for Clinical Investigation, Inc. $0021-9738 / 86 / 11 / 1375 / 12 \$ 1.00$

Volume 78, November 1986, 1375-1386
Griffonia simplicifolia I lectin, phorbol myristate acetate (PMA), ${ }^{1}$ zymosan, the calcium ionophore A23187, formylmethionylleucylphenylalanine (FMLP), Triton X-100, superoxide dismutase (S8254), $\alpha_{1}$-antitrypsin (A6150), N-chlorosuccinimide, aprotinin (A1153), phenylmethylsulfonyl fluoride (PMSF), orcein-elastin, heparin (210-6), protamine sulfate (P4020), Ficoll (F4375), and dextran (D7265) were obtained from Sigma Chemical Co. (St. Louis, MO). The PMA (1 mg/ml), PMSF (1 M), A23187 (2 mM), and FMLP (2 mM) were dissolved in dimethylsulfoxide and diluted to the appropriate concentrations in aqueous buffers. Zymosan was boiled for $5 \mathrm{~min}$ and washed three times in normal saline. It was then suspended in freshly prepared human serum at 10 $\mathrm{mg} / \mathrm{ml}$ and incubated at $37^{\circ} \mathrm{C}$ for $30 \mathrm{~min}$. The treated zymosan was then washed three times in normal saline and resuspended in the desired buffer. Azocoll was obtained from Calbiochem-Behring Corp. (La Jolla, CA). To alter the $\alpha_{1}$-antitrypsin so as to block its ability to inhibit elastase, the $\alpha_{1}$-antitrypsin was oxidized with $N$-chlorosuccinimide (14) according to the method of Shechter et al. (15). In particular, $4 \mathrm{mg}$ of $\alpha_{1}$-antitrypsin was incubated at room temperature with $0.1 \mathrm{mg}$ of $\mathrm{N}$-chlorosuccinimide in $1 \mathrm{ml}$ of $0.05 \mathrm{M}$ Tris- $\mathrm{HCl}$ buffer, $\mathrm{pH} 8.5$. After $20 \mathrm{~min}$, the sample was dialyzed to remove unreacted $N$-chlorosuccinimide. The $\alpha_{1}$-antitrypsin treated in this manner lost $100 \%$ of its ability to limit the digestion of Azocoll by porcine pancreatic elastase.

Catalase was obtained from Worthington Biochemical Corp. (Freehold, NJ) and from Sigma Chemical Co. To inactivate the catalase, the enzyme was carboxymethylated according to the method of Crestfield and colleagues (16). Loss of activity was confirmed using the assay of Bergmeyer (17). Ketamine was obtained from Park-Davis (Morris Plains, NJ). Dulbecco's modified Eagle's media, penicillin, streptomycin, amphotericin B, Hanks' balanced salt solution, and fetal bovine serum were obtained from Gibco (Grand Island, NY). Dextran sulfate $(500,000$ daltons) was obtained from Pharmacia (Uppsala, Sweden). Human neutrophil elastase was purchased from Elastin Products (Pacific, MO). Polybrene was obtained from Aldrich Chemical Co. (Milwaukee, WI). Methoxysuccinylalanylalanylprolylvalylmethylchloroketone (MeoSucala-ala-pro-val- $\mathrm{CH}_{2} \mathrm{Cl}$ ) was obtained from Enzyme Systems Products (Livermore, CA). $\mathrm{Na}_{2}\left[{ }^{51} \mathrm{Cr}\right] \mathrm{O}_{4}(500 \mathrm{mCi} / \mathrm{mg})$ and $\left[3,4,5-{ }^{3} \mathrm{H}(\mathrm{N})\right]$ leucine $(147 \mathrm{mCi} / \mathrm{mM})$, both in sterile normal saline, were obtained from New England Nuclear (Boston, MA). Anti-Mol (18, 19), anti-Mo5 (20), and anti-Ia (9-49) (21) antibodies, all monoclonal and of the IgG2a subclass, were generated and characterized as previously reported.

Alveolar epithelial cell isolation procedure. Type II alveolar epithelial cells were isolated from specific pathogen-free Fischer 344 male rats (22). In brief, the animals were anesthetized intraperitoneally with ketamine, the lung vasculature was perfused, and the airways were lavaged with Hanks' balanced salt solution lacking calcium and magnesium, and the alveolar epithelial cells were released by the intratracheal instillation of an elastase and trypsin mixture. After neutralizing the proteases, mincing the lungs, and removing the tissue pieces by filtration, the cellular suspension was incubated with Griffonia simplicifolia I lectin which agglutinates macrophages but not type II epithelial cells. After removing agglutinated cells by filtration through nylon mesh, the cells were suspended in Dulbecco's modified Eagle's medium containing $10 \%$ fetal bovine serum, 100,000 U/liter penicillin, $100 \mathrm{mg} /$ liter streptomycin, and 0.25

1. Abbreviations used in this paper: D-PBS, Dulbecco's phosphate-buffered saline; FMLP, formylmethionylleucylphenylalanine; MeoSuc-alaala-pro-val- $\mathrm{CH}_{2} \mathrm{Cl}$, methoxysuccinylalanylalanylprolylvalylmethylchloroketone; PMA, phorbol myristate acetate; PMSF, phenylmethylsulfonyl fluoride. 
$\mathrm{mg} /$ liter amphotericin B. The suspension was added to tissue culture plates and incubated for $48 \mathrm{~h}$ in a $5 \% \mathrm{CO}_{2} /$ air atmosphere at $37^{\circ} \mathrm{C}$. After $48 \mathrm{~h}$, the cells formed confluent monolayers. The cells were $>95 \%$ viable by trypan blue exclusion criterion and were $94 \pm 2 \%$ (mean \pm SD) type II cells by phosphine staining (23). The cells were joined together by tight junctions, contained cytoplasmic lamellar bodies, and incorporated palmitate into disaturated phosphatidylcholine (22).

Endothelial cells. Bovine pulmonary artery endothelial cells were provided by Dr. Una S. Ryan (University of Miami School of Medicine) (24). In our laboratory, the cells were maintained in the same medium as the epithelial cells. In preparation for cytotoxicity experiments, endothelial cells in their fifth to tenth passage were released by exposure to trypsin and ethylenediamine tetraacetic acid in Hanks' balanced salt solution lacking calcium and magnesium, $\mathrm{pH}$ 7.4. The cells were then suspended in medium and added to the wells of a 96-well plate at the same time that the epithelial cells were added. The plates were incubated for $48 \mathrm{~h}$ in $5 \% \mathrm{CO}_{2} /$ air at $37^{\circ} \mathrm{C}$ during which time the cells formed confluent monolayers.

Neutrophil isolation. Human neutrophils were isolated from heparinized $(10 \mathrm{U} / \mathrm{ml})$ peripheral venous blood by Ficoll-Hypaque density centrifugation, dextran sedimentation, and hypotonic lysis of residual erythrocytes (25). The cells were $>95 \%$ viable by trypan blue exclusion criterion. The cells were washed and maintained in Hanks' balanced salt solution lacking calcium and magnesium until immediately before use $(<1 \mathrm{~h})$. The cells were then centrifuged at $75 \mathrm{~g}$ for $10 \mathrm{~min}$ and resuspended in Dulbecco's phosphate-buffered saline containing $1 \mathrm{mg} / \mathrm{ml}$ glucose and $0.1 \mathrm{mg} / \mathrm{ml}$ bovine serum albumin (D-PBS). Neutrophils from subjects with chronic granulomatous disease were made available by Dr. John T. Curnutte (Scripps Clinic and Research Foundation, La Jolla, CA). These neutrophils failed to produce detectable superoxide when stimulated by a variety of agents including PMA. Neutrophil lysates were prepared by sonicating (model 300, Artek Systems Corp., Farmingdale, NY) suspensions of neutrophils for three 20-s bursts. Supernatants of PMA-stimulated neutrophils were obtained by placing neutrophils into wells of 96-well plates in D-PBS, allowing them to sediment onto the bottom of the plate for $15 \mathrm{~min}$, and then adding $25 \mathrm{ng} / \mathrm{ml} \mathrm{PMA}$. The plates were incubated at $37^{\circ} \mathrm{C}$ in humidified air for various periods of time. The cell-free media was removed and the supernatant used in the cytotoxicity studies. Purified neutrophil azurophilic and specific granules were provided by Dr. Curnutte. The granules were disrupted by freezethawing three times and sonicating for two 20-s bursts. Neutrophil cytoplasts were formed and isolated by the method of Roos et al. (26).

Cytotoxicity assay. Neutrophil-induced cytotoxicity was measured by a ${ }^{51} \mathrm{Cr}$-release assay. Target cells were suspended in media and placed into 96-well flat-bottomed tissue culture plates (Costar, Cambridge, MA). After $32 \mathrm{~h}$ of incubation at $37^{\circ} \mathrm{C}$ in $5 \% \mathrm{CO}_{2} /$ air, $0.8 \mu \mathrm{Ci} \mathrm{Na}{ }_{2}\left[{ }^{51} \mathrm{Cr}\right] \mathrm{O}_{4}$ was added per well and the cells incubated for an additional $16 \mathrm{~h}$. The monolayers were then washed three times with D-PBS and various reactants were added to the wells. If the cytotoxic mechanism of neutrophils was to be tested, neutrophils were mixed with appropriate inhibitors in $0.15 \mathrm{ml}$ of D-PBS and then added to each well. The plates were incubated at $37^{\circ} \mathrm{C}$ in humidified air for $15 \mathrm{~min}$ during which time the neutrophils sedimented onto the epithelial cell monolayer. Next, a neutrophil stimulus was gently added in a volume of $0.05 \mathrm{ml}$ and the plates were returned to the incubator for varying times. To determine the extent of cellular death, $0.1 \mathrm{ml}$ of medium was removed from the wells and the radioactivity was measured (TmAnalytic, Elk Grove Village, IL). If the 0.1-ml aliquot was removed with minimal agitation, the measured cytotoxicity was the same whether or not the media was centrifuged and only the supernatant was counted $(P>0.5, n=8)$. Next, $0.1 \mathrm{ml}$ of $1 \%$ Triton X-100 was added to the wells and the plates were incubated for $5 \mathrm{~min}$. After mixing the contents of the well, $0.1 \mathrm{ml}$ was removed and the radioactivity was measured. Using the results of these two measurements, it was possible to calculate both the amount of ${ }^{51} \mathrm{Cr}$ that was originally bound by the cells and the percentage that was released into the media during the incubation period. By including wells containing epithelial cells that were exposed to D-PBS without further additions, the background release of ${ }^{51} \mathrm{Cr}$ could be measured. Using this information, the percentage of specific
${ }^{51} \mathrm{Cr}$ released from neutrophil-exposed cells was calculated by: percentage of specific ${ }^{51} \mathrm{Cr}$-release $=(A-B) /(C-B) \times 100$, where $A$ is the counts per minute (cpm) released into the medium of the test sample, $B$ is the cpm released from control, unexposed cells, and $C$ is the total cpm initially bound to the cells at the beginning of the experiment.

Cytotoxicity was also measured by the release of tritium from epithelial cells previously incubated with $\left[{ }^{3} \mathrm{H}\right]$ leucine. After alveolar epithelial cells were isolated and cultured for $32 \mathrm{~h}, 0.2 \mu \mathrm{Ci}\left[{ }^{3} \mathrm{H}\right]$ leucine were added to each well. After an additional $16 \mathrm{~h}$ of culture, the monolayers were rinsed three times with D-PBS and exposed to neutrophils. The percent release of tritium was measured using the method described for ${ }^{51} \mathrm{Cr}$ release, but the $0.1-\mathrm{ml}$ aliquots were added to aqueous counting scintillant (Amersham Corp., Arlington Heights, IL) and the radioactivity was measured in a scintillation counter using $H \#$ quench correction (LS 7500, Beckman Instruments, Inc., Fullerton, CA).

Neutrophil adherence. Neutrophil adherence to epithelial cell monolayers was performed using ${ }^{51} \mathrm{Cr}$-labeled neutrophils. Neutrophils were isolated by the method outlined above and incubated with $8.0 \mu \mathrm{Ci} / \mathrm{ml}$ of $\mathrm{Na}_{2}\left[{ }^{51} \mathrm{Cr}\right] \mathrm{O}_{4}$ in Hanks' balanced salt solution lacking calcium and magnesium for $1 \mathrm{~h}$ at $37^{\circ} \mathrm{C}$. The labeled neutrophils were washed thrice and resuspended in D-PBS. Confluent monolayers of epithelial cells in 24- or 96-well plates were washed three times with D-PBS and neutrophils were added. After $15 \mathrm{~min}$ of incubation in room air at $37^{\circ} \mathrm{C}$, PMA (25 $\mathrm{ng} / \mathrm{ml}$ final concentration) was added. The plate was then incubated for 30 min without agitation. The medium in each well was removed and the wells were gently washed twice with $0.2 \mathrm{ml}$ of D-PBS. The medium and washes were pooled and the radioactivity measured. Epithelial cell monolayers remained visually intact after the washes. Alternatively, the amount of radioactivity that remained adherent to the epithelial cell monolayer was measured after washing the wells twice with D-PBS and adding $1 \%$ Triton X-100 to solubilize neutrophil-associated ${ }^{51} \mathrm{Cr}$. In addition, the amount of ${ }^{51} \mathrm{Cr}$ that leaked from PMA-stimulated neutrophils into the media during the incubation period was measured (6.5\%) and subtracted from the total counts that were contained in the media and washes. Using these measurements, the percentage of neutrophils that adhered to the epithelial cell monolayers was calculated.

Electron microscopy. Neutrophils were allowed to sediment for 15 $\mathrm{min}$ at $1 \mathrm{~g}$ onto monolayers of epithelial cells contained in 35-mm culture dishes. After adding PMA to one set of cells and incubating for $30 \mathrm{~min}$, an equal volume of $4 \%$ glutaraldehyde in $0.2 \mathrm{M}$ cacodylate buffer, $\mathrm{pH}$ 7.4, was added. After $3 \mathrm{~h}$ at $4^{\circ} \mathrm{C}$, the monolayers were gently washed twice with $0.1 \mathrm{M}$ cacodylate buffer, $\mathrm{pH} 7.4$, and postfixed with $2 \%$ osmium tetroxide for $1 \mathrm{~h}$ at $4^{\circ} \mathrm{C}$. The cells were dehydrated while still in the culture dishes with graded alcohol steps and infiltrated with $100 \%$ alcohol/ epon mixtures. The samples were embedded in 1-mm-thick epon and then snapped free from the tissue culture dishes. Thin sections were cut, stained with uranyl acetate and lead citrate, and observed in a Philips 400 transmission electron microscope (Philips Electronic Instruments, Inc., Mahwah, NJ).

Assays. Neutrophil degranulation was measured by monitoring lysozyme (27) and myeloperoxidase (28) release. Neutrophils were suspended in D-PBS with or without various potential inhibitors and stimulated with PMA. The same amount of PMA per neutrophil was used as in the cytotoxicity experiments. After $30 \mathrm{~min}$ (lysozyme) or $\mathbf{4 h}$ (myeloperoxidase) incubation at $37^{\circ} \mathrm{C}$, the cells were centrifuged at $8,000 \mathrm{~g}$ for $2 \mathrm{~min}$ and the enzyme activities of the supernatant was measured. The amount of superoxide released in $30 \mathrm{~min}$ from stimulated neutrophils was measured by the method of McCord and Fridovich (29). Hydrogen peroxide contained in medium was measured by the method of Ruch et al. (30). Elastase activity of azurophilic granules was measured using orcein-elastin as substrate and standardized against porcine pancreatic elastase (31). Nonspecific protease activity was measured against Azocoll using the procedure outlined in the Calbiochem manual (La Jolla, CA). Protein concentration was measured by the method of Lowry et al. (32) using bovine serum albumin as the standard.

Statistical analysis. For a given day on which cytotoxicity assays were performed, ${ }^{51} \mathrm{Cr}$ release was measured in quadruplicate or more for each experimental condition. Each condition was tested on at least two 
but usually three or more different days. The amount of ${ }^{51} \mathrm{Cr}$ released from epithelial cells exposed to a given number of neutrophils varied more from day to day than between replicates on the same day. To pool results from experiments performed on separate days, the data for a given condition was expressed as the percentage of specific ${ }^{31} \mathrm{Cr}$ release relative to the positive control on that day (epithelial cells exposed to PMA-stimulated neutrophils without inhibitors).

Analysis of variance with the Newman-Kuels multiple range test was used to determine the statistical significance of differences between means of various groups (33). If groups were compared only with a single control condition, then Dunnett's test was employed. A 0.05 or less probability of type I error was considered statistically significant.

\section{Results}

When monolayers of ${ }^{51} \mathrm{Cr}$-labeled epithelial cells were exposed to PMA-stimulated neutrophils, there was increased extracellular release of ${ }^{51} \mathrm{Cr}$. The amount of ${ }^{51} \mathrm{Cr}$ released increased in a timedependent fashion approaching a plateau at 8-10 h (Fig. 1). Epithelial cells exposed to medium alone spontaneously released $22.4 \pm 4.9 \%$ (mean $\pm \mathrm{SD}, n=15$ ) of their initially incorporated ${ }^{51} \mathrm{Cr}$ after $10 \mathrm{~h}$ of incubation. After $10 \mathrm{~h}$ of exposure to media alone, the monolayers appeared normal when visualized by phase-contrast microscopy, and $97.2 \pm 0.8 \%(\mathrm{SD}, n=8)$ of the cells were viable by trypan blue exclusion criterion. The addition of $1 \%$ fetal bovine serum to the media did not decrease the background release of ${ }^{51} \mathrm{Cr}(P>0.5, n=8)$.

The percentage of specific ${ }^{51} \mathrm{Cr}$ released (defined in Methods) from epithelial cells exposed to $5 \times 10^{5}$ unstimulated neutrophils or to $25 \mathrm{ng} / \mathrm{ml}$ PMA without neutrophils was not increased ( $P$ $>0.5$ ) over that of cells exposed to D-PBS alone (Table I). The amount of ${ }^{51} \mathrm{Cr}$ released from epithelial cells exposed to PMAstimulated neutrophils was dependent upon the number of neutrophils added to the wells (Fig. 2).

As another method to detect cytotoxicity, we measured release of radioactivity from epithelial cells which had been previously incubated in $\left[{ }^{3} \mathrm{H}\right]$ leucine-containing media. We found that the pattern of ${ }^{3} \mathrm{H}$ released from epithelial cells exposed to stimulated neutrophils was similar to the pattern of ${ }^{51} \mathrm{Cr}$ release (Fig. 3).

Although the majority of our studies were performed using PMA as the neutrophil activator, we also measured the cytotoxic effect of neutrophils stimulated by other agents (Table I). In

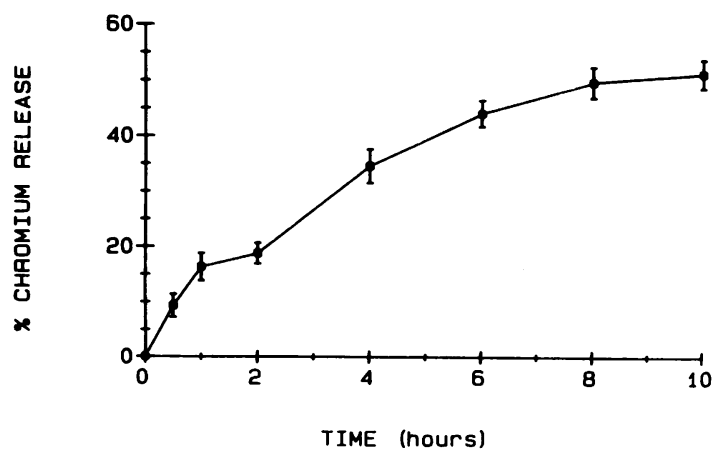

Figure 1. Kinetics of ${ }^{51} \mathrm{Cr}$ release from injured epithelial cells. Epithelial cells $\left(3.2 \times 10^{4}\right)$ as monolayers in wells of 96-well plates were exposed to $5 \times 10^{5}$ neutrophils stimulated with $25 \mathrm{ng} / \mathrm{ml}$ PMA. Epithelial cell cytotoxicity was measured by the percentage of originally bound ${ }^{51} \mathrm{Cr}$ released into the medium. The data is compiled from three experiments and expressed as the mean $\pm S E$.
Table I. Dependence of Cytotoxicity on Neutrophil Stimulus

\begin{tabular}{|c|c|c|c|}
\hline Additions to epithelial cells & $n^{*}$ & $\begin{array}{l}\text { \% specific } \\
{ }^{51} \mathrm{Cr} \text { releaseł }\end{array}$ & $P \S$ \\
\hline PMN" & 12 & $3.0 \pm 0.9$ & NST \\
\hline PMA (25 ng/ml) & 12 & $2.6 \pm 1.1$ & NS \\
\hline + PMN & 24 & $44.6 \pm 3.2$ & $<0.01$ \\
\hline $\mathrm{A} 23187^{* *}\left(1 \times 10^{-7} \mathrm{M}\right)$ & 8 & $0.3 \pm 1.6$ & NS \\
\hline + PMN & 7 & $15.2 \pm 2.2$ & $<0.01$ \\
\hline Serum-treated zymosan $(1 \mathrm{mg} / \mathrm{ml})$ & 12 & $0.3 \pm 1.2$ & NS \\
\hline$+\mathrm{PMN}$ & 12 & $18.4 \pm 1.7$ & $<0.01$ \\
\hline FMLP $\left(1 \times 10^{-5} \mathrm{M}\right)$ & 4 & $2.5 \pm 0.9$ & NS \\
\hline+ PMN & 4 & $-1.0 \pm 1.4$ & NS \\
\hline
\end{tabular}

* Number of determinations.

$\ddagger$ Results are expressed as the percentage of specific ${ }^{51} \mathrm{Cr}$ released (mean \pm SE) from monolayers of $3.2 \times 10^{4}$ epithelial cells after $10 \mathrm{~h}$ of incubation.

$\S$ Probability that the percent specific ${ }^{51} \mathrm{Cr}$ released is different from that of epithelial cells exposed to D-PBS alone.

$115 \times 10^{5}$ neutrophils (PMN) were added to each well and allowed to sediment onto the epithelial monolayers for $15 \mathrm{~min}$ before the stimulus was added.

I No statistically significant difference.

** The calcium ionophore A23187.

particular, we found that the calcium ionophore A23187 and serum-treated zymosan were able to induce neutrophils to cause increased ${ }^{51} \mathrm{Cr}$ release from epithelial cells. The chemotactic peptide FMLP did not induce increased ${ }^{51} \mathrm{Cr}$ release at up to 1 $\times 10^{-5} \mathrm{M}$ concentration.

In an effort to determine whether neutrophil-derived oxygen metabolites were involved in the injury process, we added superoxide dismutase $(310 \mathrm{U} / \mathrm{ml})$ and catalase $(9,424 \mathrm{U} / \mathrm{ml})$ to the tissue culture wells at the time of addition of neutrophils. Superoxide dismutase, which rapidly converts superoxide to hydrogen peroxide and $\mathrm{O}_{2}$, caused no reduction $(P>0.5)$ in the percentage of specific ${ }^{51} \mathrm{Cr}$ release (Table II). Catalase, which converts hydrogen peroxide to oxygen and water, caused a $26 \%$

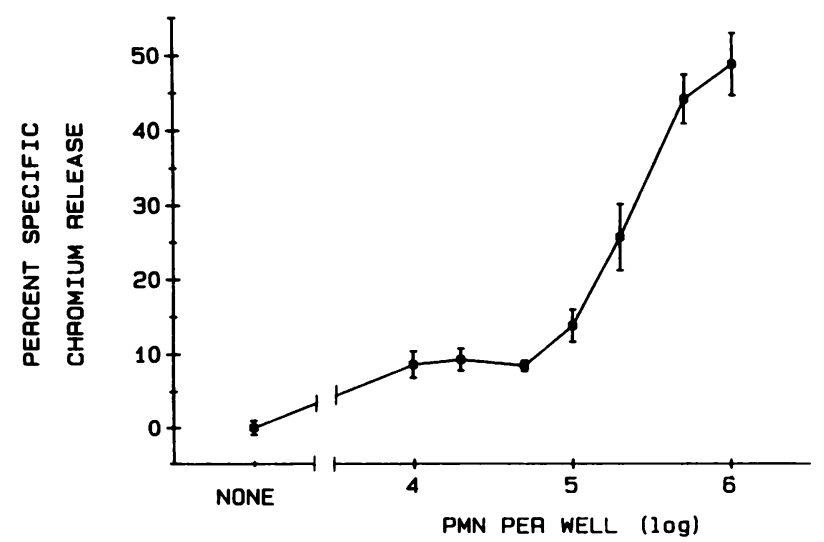

Figure 2. Dependence of epithelial cell cytotoxicity on number of stimulated neutrophils. Epithelial cells $\left(3.2 \times 10^{4}\right)$ as monolayers in wells of 96-well plates were exposed to varying numbers of neutrophils stimulated with $25 \mathrm{ng} / \mathrm{ml}$ PMA. The percentage of specific ${ }^{51} \mathrm{Cr}$ release (mean \pm SE) was measured after $10 \mathrm{~h}$ of incubation. The data is compiled from three experiments and expressed as the mean $\pm \mathrm{SE}$. 

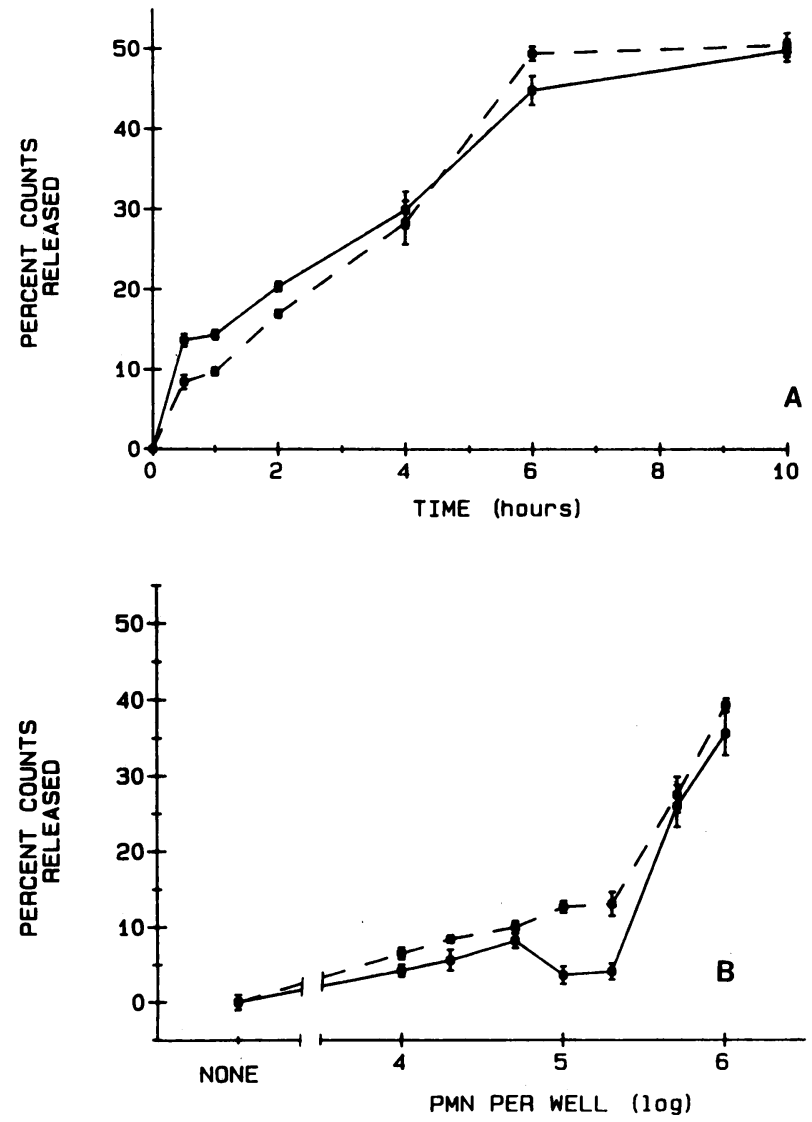

Figure 3. Comparison of $\left[{ }^{3} \mathrm{H}\right]$ leucine (--.--) and $\mathrm{Na}_{2}\left[{ }^{51} \mathrm{Cr}\right] \mathrm{O}_{4}(-)$ as indicators of epithelial cell killing by PMA-stimulated $(25 \mathrm{ng} / \mathrm{ml})$ neutrophils (PMN). The data are from a single representative experiment with each condition performed in quadruplicate and expressed as the mean \pm SE. $(A)$ Kinetics of isotope release from cells treated as in Fig. 1. (B) Dependence of isotope release on PMN number as in Fig. 2.

reduction $(P<0.01)$ in ${ }^{51} \mathrm{Cr}$ release. However, when the catalytic activity of catalase was destroyed by carboxymethylation, a statistically significant $(P<0.01)$ degree of protection remained. There was no difference $(P>0.2)$ in the ${ }^{51} \mathrm{Cr}$ released from epithelial cells exposed to neutrophils in the presence of active or inactive catalase.

To evaluate further the role of neutrophil-derived oxygen metabolites, we utilized neutrophils from subjects with chronic granulomatous disease. These neutrophils fail to release oxygen metabolites when stimulated with PMA but degranulate normally (34). Neutrophils were available from two chronic granulomatous disease subjects, one of whom donated neutrophils on two occasions. PMA-stimulated neutrophils from the chronic granulomatous disease subjects caused an increase $(P<0.001)$ in the percentage of specific ${ }^{51} \mathrm{Cr}$ released from epithelial cells compared with cells exposed to buffer alone. The amount of ${ }^{51} \mathrm{Cr}$ released from epithelial cells exposed to chronic granulomatous disease neutrophils was compared with the amount released after concurrent exposure of epithelial cells to stimulated neutrophils from normal donors (Table II). On two of three occasions, there was no difference $(P>0.5)$ in ${ }^{51} \mathrm{Cr}$ released from epithelial cells exposed to neutrophils from normal subjects or from patients with chronic granulomatous disease. On one test day, the percentage of ${ }^{51} \mathrm{Cr}$ released from epithelial cells incubated with neutrophils from a patient with chronic granu-
Table II. Role of Oxygen Metabolites in PMN-induced Damage of Epithelial Cells

\begin{tabular}{lcll}
\hline Additions to epithelial cells & $n^{*}$ & Cytotoxicity & $P \S$ \\
\hline & & $\%$ control & \\
Normal PMN + PMA & & 100 & \\
$\quad$ + SOD" & 12 & $102.3 \pm 9.8$ & NST \\
+ CAT** & 16 & $74.0 \pm 6.3$ & $<0.001$ \\
$\quad$ + inactive CAT & 15 & $82.8 \pm 4.0$ & $<0.01$ \\
CGD-1a PMN $¥$ + PMA & 7 & $49.9 \pm 8.9$ & $<.025$ \\
CGD-1b PMN + PMA & 4 & $100.2 \pm 7.3$ & NS \\
CGD-2 PMN + PMA & 4 & $107.8 \pm 9.3$ & NS \\
& & & \\
\hline
\end{tabular}

* Number of determinations.

¥ The cytotoxicity caused by a given condition was measured by the percentage of specific ${ }^{51} \mathrm{Cr}$ released from $3.2 \times 10^{4}$ epithelial cells cultured as confluent monolayers in wells of 96-well plates. Results are expressed as mean $( \pm \mathrm{SE})$ percent cytotoxicity caused by a given condition compared with a concurrently run positive control, i.e., epithelial cells exposed to $5 \times 10^{5}$ neutrophils (PMN) stimulated with $25 \mathrm{ng} / \mathrm{ml}$ PMA.

$\S$ Probability that the difference from positive control (normal PMN

+ PMA) is due to chance.

"Superoxide dismutase (SOD), $310 \mathrm{U} / \mathrm{ml}$.

I No statistically significant difference from positive control.

** Catalase (CAT), 4,924 U/ml.

¥ PMN $\left(5 \times 10^{5} /\right.$ well) from two patients (1 and 2$)$ with chronic granulomatous disease (CGD). Patient 1 was tested on two occasions ( $a$ and $b$ ).

lomatous disease (CGD-1a) was $49.9 \%$ of that induced by normal neutrophils. The cells from this same patient when tested on another day caused the same amount of injury as cells from a normal individual. The reason for the variability in the cytotoxic effect of chronic granulomatous disease neutrophils relative to that of normal neutrophils is unknown. It may be due to temporal variation in the chronic granulomatous disease patient's neutrophils or to differences in neutrophils among normal volunteer donors. No difference in the clinical condition of the chronic granulomatous disease patient was evident on the two test days.

We also tested the ability of neutrophil cytoplasts to injure epithelial cells. It has been previously demonstrated that neutrophil cytoplasts generate normal amounts of oxygen metabolites when stimulated with PMA but because they are greatly depleted of granules, they release negligible quantities of granule constitutents (26). When epithelial cells were exposed to 2.5 $\times 10^{6}$ neutrophil cytoplasts stimulated with $25 \mathrm{ng} / \mathrm{ml}$ PMA, no statistically significant increase in the percentage of specific ${ }^{51} \mathrm{Cr}$ release $(1.1 \pm 3.2$ [mean $\pm \mathrm{SE}$ ], $n=8)$ was seen. To verify that our stimulated neutrophil cytoplasts were generating oxygen metabolites, we measured the superoxide dismutase-inhibitable reduction of ferricytochrome $C$ in wells containing $2.5 \times 10^{6} \mathrm{cy}-$ toplasts stimulated with PMA. In the absence of PMA, the cytoplasts released $9.5 \mathrm{nmol}$ superoxide $/ 10^{6}$ cells over $30 \mathrm{~min}(n$ $=4$ ). In the presence of $25 \mathrm{ng} / \mathrm{ml}$ PMA, the amount of superoxide released increased to $25.7 \mathrm{nmol} / 10^{6}$ cells over $30 \mathrm{~min}$.

Based on the combination of results using superoxide dismutase, catalase, neutrophil cytoplasts, and chronic granulomatous disease neutrophils, we conclude that in our system, a substantial portion of neutrophil-induced epithelial cell killing 
is independent of neutrophil-generated oxygen metabolites. Because reports by other investigators have demonstrated that stimulated neutrophils can kill isolated endothelial cells via oxidant mechanisms (35-38), we hypothesized that our alveolar epithelial cells might be more resistant to oxidant challenge. To test this possibility, we exposed bovine pulmonary artery endothelial cells and rat alveolar epithelial cells to increasing concentrations of hydrogen peroxide and measured the cytotoxic effect using our standard assay. Using the constructed dose-response curves, we found that the concentration of hydrogen peroxide necessary to cause a $50 \%$ specific ${ }^{51} \mathrm{Cr}$ release after $10 \mathrm{~h}$ of incubation was 14 times higher for epithelial cells $(0.56 \mathrm{mM})$ than for endothelial cells $(0.04 \mathrm{mM})$.

Having demonstrated that epithelial cells were more resistant to hydrogen peroxide-induced killing compared with endothelial cells, we questioned whether this resistance was associated with a greater ability of epithelial cells to metabolize hydrogen peroxide. To answer this question, we added $200 \mu \mathrm{l}$ of $50 \mu \mathrm{M}$ hydrogen peroxide in D-PBS to wells of a 96-well plate containing monolayers of alveolar epithelial or endothelial cells. The hydrogen peroxide concentrations of the media were sampled over time and decay curves constructed (Fig. 4). The half-life of hydrogen peroxide in the media of wells containing epithelial cells (48.9 $\mathrm{min}$ ) was shorter than that of the endothelial cells (108.2 min), indicating that epithelial cells were able to metabolize hydrogen peroxide at a greater rate than endothelial cells.

To evaluate the role of neutrophil-derived proteolytic enzymes, antiproteases were added to the media. In particular, soybean trypsin inhibitor, $\alpha_{1}$-antitrypsin, aprotinin, PMSF, and MeoSuc-ala-ala-pro-val- $\mathrm{CH}_{2} \mathrm{Cl}$ were individually added. Soybean trypsin inhibitor, $\alpha_{1}$-antitrypsin, and aprotinin reduced epithelial cell killing as measured by ${ }^{51} \mathrm{Cr}$ release (Table III). PMSF accentuated neutrophil-induced injury at $0.1 \mathrm{mM}$ but protected at $1.0 \mathrm{mM}$. The reason for this biphasic response was not investigated. MeoSuc-ala-ala-pro-val- $\mathrm{CH}_{2} \mathrm{Cl}$ was toxic to epithelial cells at concentrations above $0.01 \mathrm{mM}$. When it was added to the incubation media at $0.01 \mathrm{mM}$, no epithelial cell protection

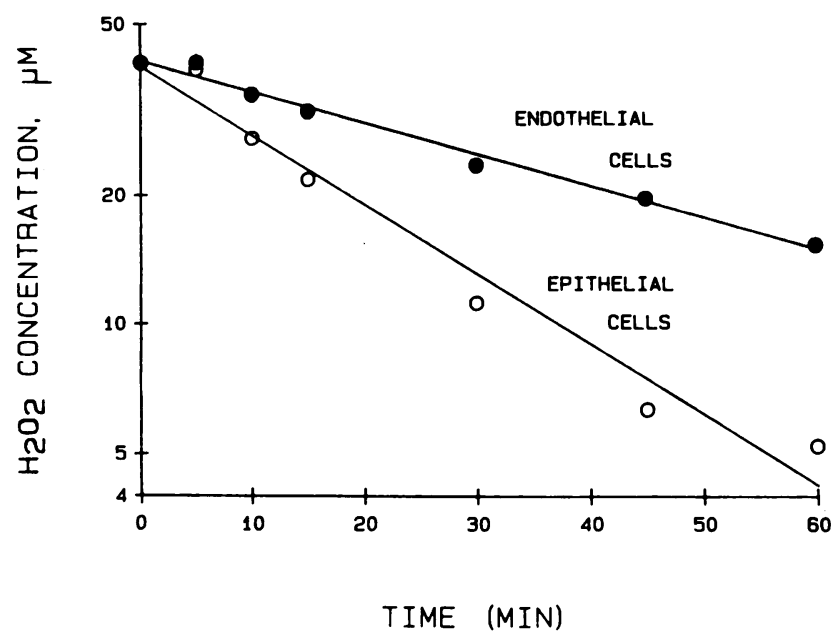

Figure 4. Kinetics of hydrogen peroxide metabolism by endothelial and epithelial monolayers. Hydrogen peroxide $(50 \mu \mathrm{M})$ in D-PBS was added to confluent monolayers of endothelial or epithelial cells contained in 96-well plates. After various times, $50 \mu \mathrm{l}$ of the originally added $200 \mu \mathrm{l}$ was removed and the concentration of hydrogen peroxide was measured. Each point represents the mean of triplicate measurements.
Table III. Role of Proteases and Serum in PMN Damage of Epithelial Cells

\begin{tabular}{|c|c|c|c|c|}
\hline \multicolumn{2}{|c|}{ Additions to epithelial cells } & $n^{*}$ & $\begin{array}{l}\text { Cytotoxicity } \\
\% \text { control }\end{array}$ & $P \S$ \\
\hline PMN + PMA & & & 100 & \\
\hline \multirow{3}{*}{$+\alpha_{1}$-antitrypsin } & $0.1 \mathrm{mg} / \mathrm{ml}$ & 16 & $90.4 \pm 6.7$ & NS" \\
\hline & $0.3 \mathrm{mg} / \mathrm{ml}$ & 8 & $93.8 \pm 9.1$ & NS \\
\hline & $1.0 \mathrm{mg} / \mathrm{ml}$ & 12 & $55.6 \pm 4.1$ & $<0.05$ \\
\hline \multirow[t]{3}{*}{ + SBTII } & $0.1 \mathrm{mg} / \mathrm{ml}$ & 12 & $88.9 \pm 6.3$ & $<0.05$ \\
\hline & $0.3 \mathrm{mg} / \mathrm{ml}$ & 8 & $86.2 \pm 5.1$ & $<0.05$ \\
\hline & $1.0 \mathrm{mg} / \mathrm{ml}$ & 12 & $45.8 \pm 4.0$ & $<0.01$ \\
\hline \multirow[t]{3}{*}{+ aprotinin } & $0.1 \mathrm{mg} / \mathrm{ml}$ & 12 & $95.4 \pm 3.7$ & NS \\
\hline & $0.3 \mathrm{mg} / \mathrm{ml}$ & 12 & $86.0 \pm 3.0$ & NS \\
\hline & $1.0 \mathrm{mg} / \mathrm{ml}$ & 16 & $47.2 \pm 6.6$ & $<0.05$ \\
\hline \multirow[t]{3}{*}{$+\mathrm{PMSF}^{* *}$} & $0.1 \mathrm{mM}$ & 20 & $128.2 \pm 8.8$ & $<0.05$ \\
\hline & $0.3 \mathrm{mM}$ & 16 & $118.7 \pm 7.7$ & NS \\
\hline & $1.0 \mathrm{mM}$ & 20 & $76.4 \pm 6.9$ & $<0.05$ \\
\hline \multirow[t]{2}{*}{ + FBSłł } & $1 \%(\mathrm{vol} / \mathrm{vol})$ & 16 & $69.2 \pm 8.2$ & $<0.01$ \\
\hline & $10 \%(\mathrm{vol} / \mathrm{vol})$ & 16 & $41.8 \pm 7.5$ & $<0.01$ \\
\hline
\end{tabular}

* Number of determinations.

$¥$ Cytotoxicity was measured and data expressed as in Table II.

$\S$ Probability that the difference from positive control is due to chance.

"No statistically significant difference from positive control (PMN

+ PMA).

I Soybean trypsin inhibitor (SBTI).

** Phenylmethylsulfonyl fluoride (PMSF).

¥¥ Fetal bovine serum (FBS).

was noted. As a control condition, $1 \mathrm{mg} / \mathrm{ml}$ bovine serum albumin was added and no reduction in ${ }^{51} \mathrm{Cr}$ release was seen (data not shown). Fetal bovine serum which contains several antiproteases also inhibited epithelial cell killing (Table III).

To determine whether the protective effect of $\alpha_{1}$-antitrypsin was dependent upon its ability to inhibit neutrophil elastase, $\alpha_{1-}$ antitrypsin was oxidized with $\mathrm{N}$-chlorosuccinimide, a process which destroys its elastase-inhibitory activity (14). We then added either native or oxidized $\alpha_{1}$-antitrypsin to the cytotoxicity assay system. We found that the protective effect of $1 \mathrm{mg} / \mathrm{ml}$ native $\alpha_{1}$-antitrypsin (65.1 \pm 5.5 [SE] percent inhibition of cytotoxicity) was not decreased $(P>0.5, n=8)$ when it was replaced by oxidized $\alpha_{1}$-antitrypsin (62.2 \pm 4.9 percent inhibition).

Experiments were also performed to test the effect of combining antioxidants and antiproteases. In separate experiments, we found that the reduction in killing associated with $1.0 \mathrm{mg} /$ $\mathrm{ml}$ soybean trypsin inhibitor ( $29.9 \%$ inhibition) was not further reduced $(P>0.5, n=4)$ when $0.1 \mathrm{mg} / \mathrm{ml}$ catalase was added (25.9\% inhibition). Similarly, the reduction in cytotoxicity associated with $1 \mathrm{mg} / \mathrm{ml} \alpha_{1}$-antitrypsin (36.4\% inhibition) was not further reduced $(P>0.5, n=4)$ when $0.1 \mathrm{mg} / \mathrm{ml}$ catalase was added (32.0\% inhibition).

Another class of neutrophil products which may potentially cause epithelial cell injury are the granule cationic proteins (3943). To evaluate this possibility, epithelial cells were exposed to stimulated neutrophils in the presence of two polyanions, heparin and dextran sulfate. It has been previously reported that polyanions inhibit cationic protein-dependent microbicidal activity $(39,40,42)$. Both heparin and dextran sulfate limited the amount of epithelial cell lysis (Table IV). To determine whether protec- 
Table IV. Inhibition of PMN-induced Damage of Epithelial Cells by Polyanions

\begin{tabular}{clrll}
\hline Additions to epithelial cells & & $n^{*}$ & Cytotoxicity & $P \S$ \\
\hline & & & \% control & \\
PMN + PMA & & & 100 & \\
+ heparin & $0.02 \mathrm{U} / \mathrm{ml}$ & 8 & $84.6 \pm 5.8$ & $<0.01$ \\
& $0.2 \mathrm{U} / \mathrm{ml}$ & 8 & $83.1 \pm 5.9$ & $<0.01$ \\
& $2.0 \mathrm{U} / \mathrm{ml}$ & 16 & $36.0 \pm 4.1$ & $<0.01$ \\
+ dextran sulfate & $0.001 \mathrm{mg} / \mathrm{ml}$ & 8 & $63.9 \pm 8.0$ & $<0.01$ \\
& $0.01 \mathrm{mg} / \mathrm{ml}$ & 12 & $35.8 \pm 4.2$ & $<0.01$ \\
+ dextran & $0.1 \mathrm{mg} / \mathrm{ml}$ & 12 & $31.6 \pm 6.5$ & $<0.01$ \\
& $0.001 \mathrm{mg} / \mathrm{ml}$ & 12 & $98.2 \pm 6.6$ & $\mathrm{NS}$ \\
& $0.01 \mathrm{mg} / \mathrm{ml}$ & 12 & $86.4 \pm 7.7$ & $\mathrm{NS}$ \\
& $0.1 \mathrm{mg} / \mathrm{ml}$ & 11 & $81.5 \pm 8.5$ & $\mathrm{NS}$
\end{tabular}

* Number of determinations.

¥ Cytotoxicity measured and results expressed as in Table II.

$\S$ Probability that the difference from positive control (PMN + PMA) is due to chance.

"No statistically significant difference from positive control.

tion by dextran sulfate was dependent upon the electrical charge of the molecule, cytotoxicity assays were performed using uncharged dextran. We found that the neutrophil-induced cytotoxicity was not diminished in the presence of uncharged dextran.

Because the above studies suggested that neutrophil granule contents might be causing the injury, we tested the cytotoxic effect of various neutrophil fractions. To determine whether neutrophil lysates contained cytotoxic factors, epithelial cells were exposed to neutrophils which had been disrupted by sonication for $30 \mathrm{~s}$. No significant increased ${ }^{51} \mathrm{Cr}$ release was seen (Table V). Because many of the neutrophil proteases and cationic proteins are contained in azurophilic granules, we exposed monolayers of epithelial cells to the contents of purified azurophilic granules (Table V). When epithelial cells were incubated with up to $0.1 \mathrm{mg} / \mathrm{ml}$ azurophilic granule protein, no significant cellular lysis was detected. Similarly, when epithelial cells were exposed to $0.1 \mathrm{mg} / \mathrm{ml}$ specific granule protein, no increased cytotoxicity was observed. It is possible that neutrophil azurophilic granules do contain the agents responsible for the observed epithelial cell injury, but the agents are inactivated during preparation. To partially address this possibility, we measured the ability of the isolated azurophilic granules to digest two different substrates. Using porcine pancreatic elastase as a standard for comparison, we found the presence of proteolytic activity in our preparations of azurophilic granules. The specific activity was 2.1 $\pm 0.2(\mathrm{SD}) \mathrm{U} / \mathrm{mg}$ granule protein toward elastin-orcein and 9.4 $\pm 2.3 \mathrm{U} / \mathrm{mg}$ granule protein toward Azocoll (a substrate that detects a broad range of protease activities).

We also used purified human neutrophil elastase in our cytotoxicity assay. We found that elastase in the amount contained in $2 \times 10^{6}$ neutrophils (44) failed to increase the percentage of specific ${ }^{51} \mathrm{Cr}$ release (Table V). In addition to the proteases contained within the granular fractions of neutrophils, protease activity has also been found associated with neutrophil plasma membranes (45). We were not able to implicate plasma membrane-associated proteases as a cause of increased ${ }^{51} \mathrm{Cr}$ release in that lysed neutrophils (Table V) and neutrophil cytoplasts did not injure the cells.
Table V. Cytotoxic Effect of PMN-derived Products

\begin{tabular}{lrrl}
\hline Additions to epithelial cells & $n^{*}$ & $\begin{array}{l}\text { \% specific } \\
{ }^{11} \mathrm{Cr} \text { releasef }\end{array}$ & $P \S$ \\
\hline Lysed PMN & & & \\
$5 \times 10^{5}$ PMN" & 12 & $1.6 \pm 1.9$ & NST \\
$2 \times 10^{6}$ PMN & 12 & $1.2 \pm 1.4$ & NS \\
PMN azurophilic granule contents & & & \\
$2 \mu \mathrm{g}, 8 \times 10^{5}$ PMN" & 20 & $-1.5 \pm 1.1$ & NS \\
$20 \mu \mathrm{g}, 8 \times 10^{6}$ PMN & 24 & $-1.3 \pm 1.3$ & NS \\
PMN specific granule contents & & & \\
$10 \mu \mathrm{g}, 8 \times 10^{6}$ PMN" & 4 & $0.6 \pm 0.8$ & NS \\
$20 \mu \mathrm{g}, 1.6 \times 10^{7}$ PMN & 4 & $-0.2 \pm 0.8$ & NS \\
Supernatants of PMA-stimulated PMN & & & \\
$5 \times 10^{5}$ PMN** & 20 & $4.4 \pm 1.1$ & $<0.01$ \\
$2 \times 10^{6}$ PMN & 12 & $3.6 \pm 1.4$ & $<0.05$ \\
Human neutrophil elastase & & & \\
$1.7 \mu \mathrm{g}, 2 \times 10^{6}$ PMN" & 8 & $-0.8 \pm 1.1$ & NS \\
\hline
\end{tabular}

* Number of determinations.

$\ddagger$ Results are expressed as the percentage of specific ${ }^{51} \mathrm{Cr}$ released (mean \pm SE) from monolayers of $3.2 \times 10^{4}$ epithelial cells after $10 \mathrm{~h}$ of incubation.

$\S$ Probability that the percentage of specific ${ }^{51} \mathrm{Cr}$ released is different from that of epithelial cells exposed to D-PBS alone.

"Number of neutrophils (PMN) that would contain the given weight of granule protein that was added to each well.

I No statistically significant difference.

** Number of PMN that were stimulated to generate supernatant that was added to each well.

To determine whether a stable cytotoxic factor was released into the media by PMA-stimulated neutrophils, epithelial cells were exposed to supernatants from wells in which PMA-stimulated neutrophils were incubated for $10 \mathrm{~h}$. A statistically significant, although quantitatively small, increase in the percentage of specific ${ }^{51} \mathrm{Cr}$ release was noted (Table V). The inability of stimulated neutrophil supernatants to cause substantial cytotoxicity also demonstrates that neutrophil-induced killing was not caused by depletion of a vital factor from the media. To determine whether a metastable cytotoxic factor was released by neutrophils but inactivated during the 10 -h incubation, neutrophils were placed into wells and after sedimenting for $15 \mathrm{~min}$ were stimulated with PMA. After an additional 15 or $30 \mathrm{~min}$, the supernatants were transferred to wells containing ${ }^{51} \mathrm{Cr}$-labeled epithelial cells and the cytotoxicity was measured after $10 \mathrm{~h}$ of incubation. No significant increase in the percentage of specific ${ }^{51} \mathrm{Cr}$ release was noted $(P>0.2, n=4)$.

We tested the possibility that protection caused by the abovementioned agents was due to reductions in neutrophil viability. Neutrophils preincubated with ${ }^{51} \mathrm{Cr}$ were stimulated with $25 \mathrm{ng} /$ ml PMA in the presence of the various antiproteases and polyanions. None of the inhibitors caused increased extracellular release of ${ }^{51} \mathrm{Cr}$ when tested at the highest concentrations used in the cytotoxicity studies $(P>0.4)$. We also considered that the protection associated with the previously mentioned agents might be due to inhibition of neutrophil activation. We found that the release of superoxide $\left(23.8 \mathrm{nmol} / 10^{6}\right.$ cells over $\left.30 \mathrm{~min}\right)$ from PMA-stimulated neutrophils was not reduced by the presence of inhibitors that were used in the previously mentioned 
experiments $(P>0.05)$. Similarly, the percentage of lysozyme released after PMA stimulation ( $31.8 \%$ in $30 \mathrm{~min}, n=8$ ) was not reduced by the presence of the inhibitors $(P>0.5)$. PMA, which is known to be a relatively poor agonist for myeloperoxidase secretion, caused $11.9 \%$ of neutrophil myeloperoxidase to be released after $4 \mathrm{~h}$ of incubation $(n=4)$. None of the inhibitors reduced this by $>1.5 \%$.

During the cytotoxicity studies using intact neutrophils, the neutrophils were allowed to sediment onto the epithelial cell monolayers before PMA was added. If PMA was not added, few of the neutrophils adhered during an additional $30 \mathrm{~min}$ of incubation (Table VI). In contrast, if PMA was added, most of the neutrophils adhered by $30 \mathrm{~min}$. To determine whether neutrophil adherence was an important factor in the cytotoxic process, a monoclonal antibody (anti-Mol) was used because it inhibits neutrophil adhesive interactions (46). Anti-Mol does not alter activation of neutrophils that have been exposed to soluble stimuli (19). To determine whether anti-Mol antibody would inhibit neutrophil adherence to epithelial monolayers, ${ }^{51} \mathrm{Cr}$-labeled neutrophils were pretreated with anti-Mol antibody for $10 \mathrm{~min}$. The neutrophil suspension was then transferred to a 24-well plate containing monolayers of epithelial cells. After $15 \mathrm{~min}, \mathrm{PMA}(25 \mathrm{ng} / \mathrm{ml})$ was added and neutrophil adherence was measured after an additional 30 min as described in Methods. We found that anti-Mol antibody reduced the adherence of neutrophils to epithelial cell monolayers (Table VI). By indirect immunofluorescence analysis, we found that anti-Mol antibody, which is known to bind to neutrophils, did not bind to the epithelial cells. Therefore, we believe that the ability of anti-Mol antibody to inhibit neutrophil adherence to epithelial cells was due to its effect on neutrophils and not on epithelial cells. To determine whether the inhibition might be a nonspecific effect of antibody, parallel experiments were performed using two other IgG2a monoclonal antibodies, anti-Mo5 and an antiIa. Anti-Mo5 antibody binds to human neutrophils but does not alter aggregation (47) or activation (19). The anti-Ia antibody does not bind to neutrophils. We found that anti-Mo5 and antiIa antibodies did not inhibit neutrophil adherence to epithelial cell monolayers (Table VI).

To demonstrate the alteration visually in cell-cell contact

Table VI. PMN Adherence to Epithelial Cell Monolayers

\begin{tabular}{lccc}
\hline Additions to PMN & $n^{*}$ & PMN adherence & $P \S$ \\
\hline & & \% of added PMN & \\
None & 4 & $3.2 \pm 1.2$ & - \\
PMA & 6 & $90.6 \pm 2.0$ & - \\
PMA + anti-Mo1" & 6 & $50.7 \pm 7.4$ & $<0.001$ \\
PMA + anti-Mo5 & 5 & $89.4 \pm 2.4$ & NST \\
PMA + anti-Ia & 5 & $91.6 \pm 0.9$ & NS \\
\hline
\end{tabular}

* Number of determinations.

$\ddagger$ Percentage (mean \pm SE) of $3 \times 10^{6}$ neutrophils $(\mathrm{PMN}$ ) that adhered to epithelial cell monolayers in wells of 24-well plates $30 \mathrm{~min}$ after addition of $25 \mathrm{ng} / \mathrm{ml}$ PMA or control buffer.

$\S$ Probability that the difference in PMN adherence under the given condition compared with PMA alone is due to chance.

" Purified monoclonal antibodies $(5 \mu \mathrm{g} / \mathrm{ml})$ were preincubated with

PMN for 10 min as described in Methods.

II No statistically significant difference. caused by the anti-Mol antibody, neutrophils were allowed to sediment onto epithelial cells for $15 \mathrm{~min}$ in the presence of either anti-Mol or anti-Mo5 antibody. PMA was then added, and after 30 min of incubation, the cells were fixed by gently adding an equal volume of $4 \%$ glutaraldehyde (Fig. 5). In cultures containing anti-Mol antibody, the neutrophils appeared rounded and had limited contact with the underlying epithelial cell monolayer. When anti-Mo5 antibody was used as a control condition, the PMA-stimulated neutrophils had an extensive area of contact with the epithelial cell monolayer.

The effect of anti-Mol antibody on neutrophil-induced epithelial cell cytotoxicity was tested in our standard assay. Neutrophils were pretreated with antibody for $10 \mathrm{~min}$ and then the cellular suspension was added to 96 -well plates containing ${ }^{51} \mathrm{Cr}$ labeled epithelial cell monolayers. After 15 min, PMA was gently added, and the percentage of specific ${ }^{51} \mathrm{Cr}$ release was measured after $10 \mathrm{~h}$. We found that anti-Mol antibody caused a dosedependent reduction in ${ }^{51} \mathrm{Cr}$ released from epithelial cells (Table VII). As control conditions, the effects of anti-Mo5 and anti-Ia were also tested. These two antibodies caused only slight inhibition of neutrophil-induced injury of epithelial cells. The doseresponse experiments were performed using monoclonal antibodies contained in mouse ascitic fluid. The results were confirmed using purified antibodies at one concentration (Table VII).

To determine the critical time during which adherence is important, we exposed epithelial cells to neutrophils that had been stimulated with PMA at various times before being transferred to the epithelial cell-containing wells (Table VIII). Compared with our usual protocol in which neutrophils were allowed to sediment onto the monolayers before the PMA was added, we found that cytotoxicity was less if the PMA was added simultaneously with the neutrophils. The longer the time interval between stimulation and transfer of neutrophils to the wells, the less cytotoxicity was noted. If $10 \mathrm{~min}$ elapsed, the amount of ${ }^{51} \mathrm{Cr}$ release was not greater than that of unexposed epithelial cells.

Because neutrophil adherence appeared to be important for cytotoxicity, we questioned whether some of the protection noted in experiments using inhibitors might be due to alterations in adherence rather than the intended mechanism. To test this possibility, neutrophils were added to epithelial cells in the presence of the various inhibitors. After allowing $15 \mathrm{~min}$ for the neutrophils to sediment onto the epithelial cell monolayer, phorbol myristate etate $(25 \mathrm{ng} / \mathrm{ml})$ was added. After an additional $30 \mathrm{~min}$ of incubation, the percentage of neutrophil adherence was measured as outlined in Methods. As noted previously, we found that relatively few unstimulated neutrophils adhered to the epithelial cell monolayer (Table IX). In contrast, the majority of neutrophils stimulated with PMA adhered to the monolayer. The antiproteases soybean trypsin inhibitor, $\alpha_{1}$-antitrypsin, aprotinin, and fetal bovine serum reduced the adherence of neutrophils to the epithelial monolayer. The reduced adherence associated with fetal bovine serum was not due to species differences between the serum and cells because similar reductions in adherence were noted with human or rat serum (data not shown). The reduced adherence was not due to a nonspecific effect of protein in that PMA-stimulated neutrophils adhered normally in the presence of bovine serum albumin. The polyanions heparin and dextran sulfate were associated with small but statistically insignificant reductions in neutrophil adherence to epithelial cells. 

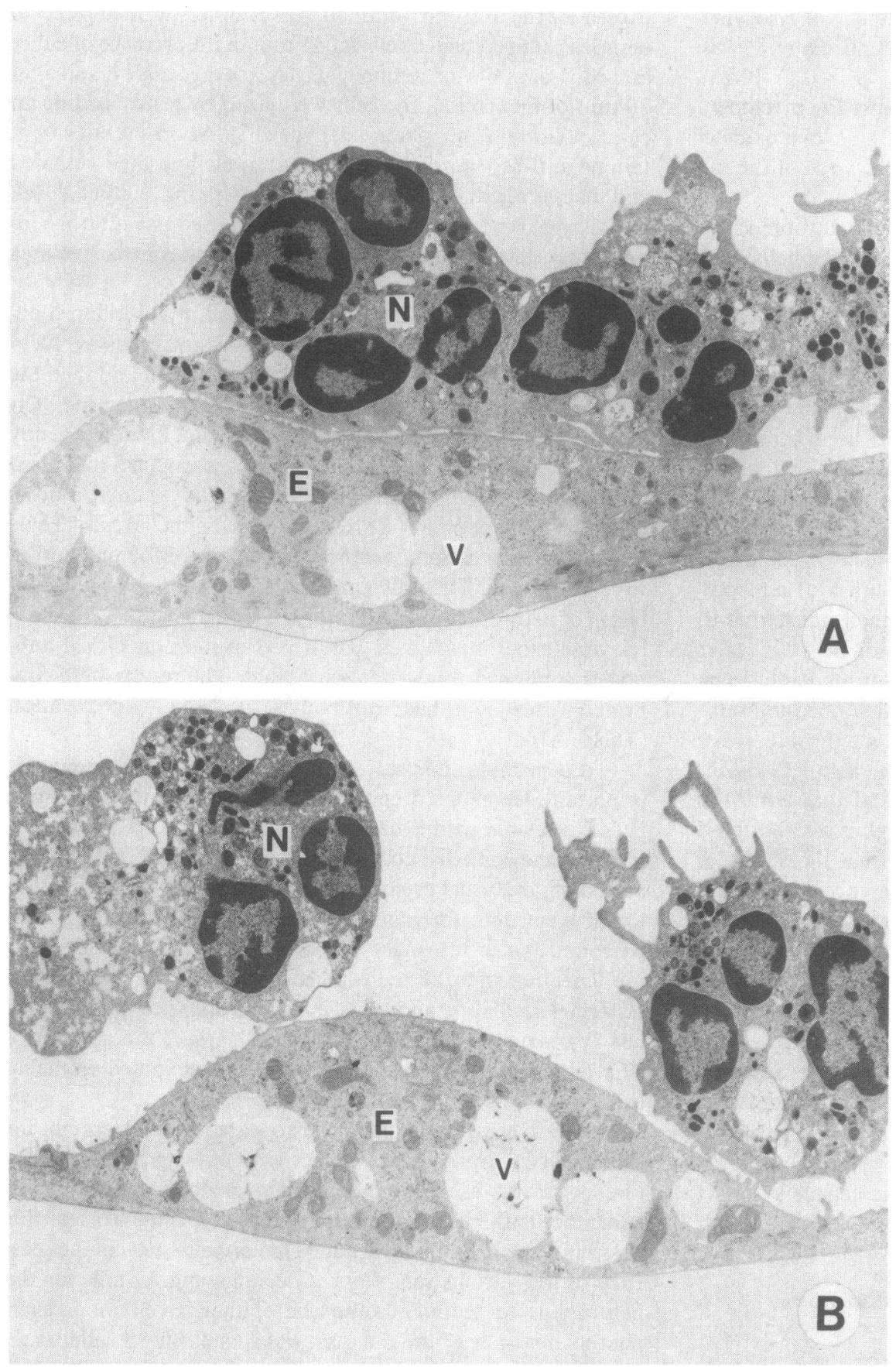

Figure 5. Transmission electron micrographs of PMA-stimulated neutrophils $(N)$ on monolayers of alveolar epithelial cells $(E) .(A)$ Neutrophils pretreated with $5 \mu \mathrm{g} / \mathrm{ml}$ anti-Mo5 antibody as a control condition. This antibody does not affect neutrophil adherence or cytotoxicity $(X$ $2,800)$. (B) Neutrophils pretreated with 5 $\mu \mathrm{g} / \mathrm{ml}$ anti-Mol antibody which reduces neutrophil adherence and cytotoxicity toward epithelial cells. Vacuoles $(v)$ in epithelial cells contained lammelar bodies which were washed out during processing (22) $(\times 4,850)$.

\section{Discussion}

Neutrophil-induced killing of alveolar epithelial cells by a mechanism independent of neutrophil-generated oxygen metabolites has not been previously described. In this study we measured epithelial cell damage by monitoring the extracellular release of ${ }^{51} \mathrm{Cr}$ from previously labeled cells. This technique has been previously used as a measurement of cellular death by many investigators, some of whom are cited for other reasons in this paper $(35-38,40,42,48-50)$. In this study, we confirmed the presence of cellular damage by an additional technique. Cells were preincubated with $\left[{ }^{3} \mathrm{H}\right]$ leucine to allow a radioactive marker to be incorporated into cellular macromolecules. The pattern of extracellular leakage of ${ }^{3} \mathrm{H}$ from epithelial cells exposed to stimulated neutrophils closely approximated that of ${ }^{51} \mathrm{Cr}$ suggesting that both methods were measuring loss of epithelial cell integrity.

Neutrophil-mediated injury of epithelial cells could be induced by several neutrophil stimuli. Although PMA was associated with the greatest amount of epithelial cell injury, we found that the calcium ionophore A23178 and serum-treated zymosan were also able to stimulate neutrophils to cause increased ${ }^{51} \mathrm{Cr}$ release from epithelial cells. Thus, the processes leading to epithelial injury are not due to unique PMA effects but can also be initiated by another, unrelated soluble stimulus (A23187) and by a particulate stimulus (serum-treated zymosan).

Suttorp and Simon (49) previously reported that mouse peritoneal neutrophils were able to kill monolayers of $\mathrm{L} 2$ cells. 
Table VII. Inhibition of PMN-induced Epithelial Cell Cytotoxicity by Anti-Mol Antibody

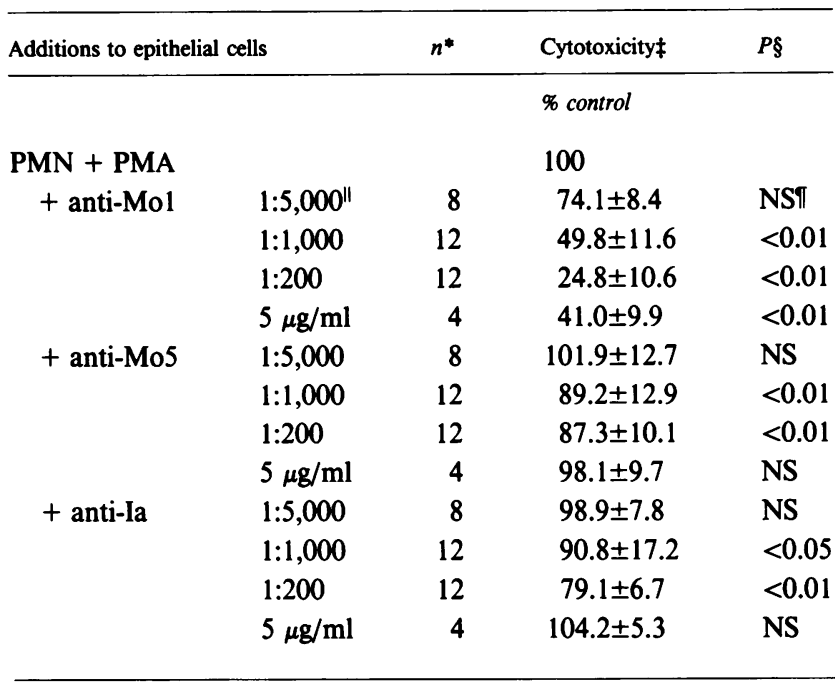

* Number of determinations.

$¥$ Cytotoxicity measured and results expressed as in Table II.

$\S$ Probability that the difference from positive control (PMA + PMN)

is due to chance.

"Dilution of immune mouse ascites or concentration of purified monoclonal antibody added to PMN suspension.

I No statistically significant difference.

L2 cells are epithelial cells derived from a clone of rat type II pneumocytes (51). It was concluded that the injury was caused by oxygen metabolites because catalase, a scavenger of hydrogen peroxide, was able to protect the epithelial cells. Heat-inactivated catalase was not effective. In our experiments, we found that catalase had only weak protective effect which persisted when the catalase was inactivated by carboxymethylation. We did not use heat-inactivated catalase because we found that catalase precipitated upon heating. The killing of epithelial cells by neutro-

Table VIII. Dependence of Cytotoxicity on Time between PMN Activation and Their Transfer onto Epithelial Cell Monolayers

\begin{tabular}{|c|c|c|}
\hline Time* & \% specific ${ }^{31} \mathrm{Cr}$ releaseł & $P \S$ \\
\hline \multicolumn{3}{|l|}{$\min$} \\
\hline$-15^{\prime \prime}$ & $34.5 \pm 2.9$ & \\
\hline 0 & $28.5 \pm 3.0$ & $<0.05$ \\
\hline 2 & $14.5 \pm 3.3$ & $<0.001$ \\
\hline 5 & $16.1 \pm 1.4$ & $<0.001$ \\
\hline 10 & $1.3 \pm 1.0$ & $<0.001$ \\
\hline 30 & $2.9 \pm 0.9$ & $<0.001$ \\
\hline
\end{tabular}

* $5 \times 10^{5}$ neutrophils (PMN) were stimulated with $25 \mathrm{ng} / \mathrm{ml}$ PMA in test tubes and transferred to wells containing $3.2 \times 10^{4}$ epithelial cells after varying times.

$¥$ Results are expressed as the percentage of specific ${ }^{51} \mathrm{Cr}$ released (mean \pm SE, $n=4$ ) from epithelial cells after $10 \mathrm{~h}$ of exposure to stimulated neutrophils.

$\S$ Probability that the difference from " $-15 \mathrm{~min}$ " is due to chance.

"In accordance with our standard cytotoxicity assay protocol, unstimulated neutrophils were added to wells and allowed to sediment for 15 min, after which PMA was added.
Table IX. Neutrophil Adherence to Epithelial Cell Monolayers

\begin{tabular}{|c|c|c|c|}
\hline Additions to PMN & $n^{*}$ & PMN adherenceł & $P \S$ \\
\hline & & $\%$ of total added & \\
\hline None & 28 & $9.5 \pm 0.8$ & \\
\hline PMA & 83 & $90.2 \pm 3.7$ & \\
\hline + catalase $(0.1 \mathrm{mg} / \mathrm{ml})$ & 16 & $78.3 \pm 5.6$ & $<0.01$ \\
\hline$+\operatorname{SBTI}^{\|}(1.0 \mathrm{mg} / \mathrm{ml})$ & 14 & $72.3 \pm 6.8$ & $<0.01$ \\
\hline$+\alpha_{1}$-antitrypsin $(1.0 \mathrm{mg} / \mathrm{ml})$ & 15 & $70.0 \pm 6.0$ & $<0.01$ \\
\hline+ aprotinin $(1.0 \mathrm{mg} / \mathrm{ml})$ & 14 & $71.4 \pm 4.7$ & $<0.01$ \\
\hline + PMSF $(1 \mathrm{mM})$ & 16 & $84.2 \pm 2.4$ & $\mathrm{NS}^{* *}$ \\
\hline \multicolumn{4}{|l|}{+ fetal bovine serum } \\
\hline$(10 \%$, vol/vol $)$ & 16 & $31.8 \pm 4.8$ & $<0.01$ \\
\hline \multicolumn{4}{|l|}{+ bovine serum albumin } \\
\hline$(1 \mathrm{mg} / \mathrm{ml})$ & 4 & $95.0 \pm 5.3$ & NS \\
\hline+ heparin $(2 \mathrm{U} / \mathrm{ml})$ & 16 & $85.9 \pm 2.0$ & NS \\
\hline+ dextran sulfate $(0.01 \mathrm{mg} / \mathrm{ml})$ & 16 & $81.5 \pm 1.8$ & NS \\
\hline+ dextran $(0.01 \mathrm{mg} / \mathrm{ml})$ & 16 & $88.6 \pm 2.0$ & NS \\
\hline
\end{tabular}

* Number of determinations.

$\ddagger$ Suspensions of $5 \times 10^{5}$ neutrophils (PMN) containing the designated inhibitors were added to confluent monolayers of epithelial cells contained in wells of a 96-well plate. After $15 \mathrm{~min}$, PMA $(25 \mathrm{ng} / \mathrm{ml})$ was added. After $30 \mathrm{~min}$ of incubation, PMN adherence was measured as indicated in Methods.

$\S$ Probability that the difference from PMN + PMA is due to chance.

"Soybean trypsin inhibitor (SBTI).

I Phenylmethylsulfonyl fluoride (PMSF).

** No statistically significant difference.

phils from chronic granulomatous disease patients provided additional strong evidence that neutrophil-produced oxygen metabolites were not required for the cytotoxic effect in our system. Neutrophil cytoplasts, which release oxygen metabolites when stimulated, were also ineffective in killing epithelial cells. One possible explanation for the differences between our results and those of Suttorp and Simon is that the sources of effector and target cells were different. We used primary cultures of rat alveolar epithelial cells and human peripheral blood neutrophils as opposed to their use of $\mathrm{L} 2$ cells and elicited mouse peritoneal neutrophils. Although L2 cells are morphologically similar to type II epithelial cells, they differ significantly in biochemical properties (52).

Other investigators have demonstrated that in some experimental systems, neutrophils can kill cultured endothelial cells using oxygen radicals (35-38). Because we found that neutrophilgenerated oxidants did not play a major role in the killing of alveolar epithelial cells, it would appear that the epithelial cells were more resistant to exogenous oxidants. We confirmed this by demonstrating that the concentration of hydrogen peroxide necessary to kill $50 \%$ of the target cells was 14 times higher for epithelial than for bovine pulmonary artery endothelial cells. The alveolar epithelial cells also metabolized exogenously added hydrogen peroxide at a faster rate than did the endothelial cells. Varani and colleagues (38) have studied these endothelial cells and demonstrated that oxygen metabolites were involved in the process of neutrophil-induced injury.

Ayars and colleagues (50) also studied the effects of PMAstimulated neutrophils on alveolar epithelial cells. In contrast to our results, they did not find neutrophil-induced killing as 
measured by a ${ }^{51} \mathrm{Cr}$-release assay. Similarly to the present study, these authors used rat alveolar epithelial cells and human neutrophils. The reasons for the discrepancy are unknown but may be secondary to a variety of factors. For example, the response of neutrophils to stimuli depends upon the technique used to isolate the cells (53). In addition, there are differences between studies in the procedures used to isolate rat epithelial cells and in their time in culture. Also, the media used in the cytotoxicity experiments differed. A similar situation exists in the field of neutrophil-induced endothelial cell injury in which the studies performed by some investigators demonstrate neutrophil-induced killing (35-38) whereas others do not (48). Instead of epithelial cell killing, Ayars and colleagues (50) found and characterized a neutrophil-induced detachment of epithelial cells from the culture dish. Our study was not designed to address this phenomenon.

Close apposition of neutrophil and epithelial cell membranes appeared to be important for optimal killing. A requirement for close contact between neutrophil and target cell has been described in other systems $(35,54,55)$. We noted that cytotoxicity in our system decreased when adherence of neutrophils to epithelial cells was reduced by pretreatment with anti-Mol antibody (specific for an adhesion-promoting neutrophil glycoprotein [gp155,94] [46]). Other investigators have used this approach to examine the role of adherence in neutrophil-induced injury of cultured endothelial cells (56). In particular, these authors used a monoclonal antibody (MAb 60.3) which binds to a different epitope of gp155,94 but also inhibits adherence.

Neutrophils treated with anti-Mol antibody still sedimented onto the epithelial monolayer and were thus physically close to their targets. However, transmission electron microscopy indicated that extensive membrane-membrane contact did not occur as it did in anti-Mo5-treated control cells. This reduced contact was quantified by reduced neutrophil adherence to epithelial cells. Apparently, it was insufficient for the neutrophils to be merely close to epithelial cells in order to kill them. Extensive contact between neutrophil and epithelial cell membranes appeared to be required. We speculate that intimate contact may be important by allowing the neutrophil to subject the target cell to very high concentrations of its secretory products. Alternatively, the neutrophil cytotoxic mechanism may be membrane bound, thus requiring physical contact between neutrophil and target cell.

We found that a variety of antiproteases partially protected epithelial cells from neutrophil-induced injury. However, when intact neutrophils were replaced with either neutrophil lysates, neutrophil-conditioned media, purified neutrophil azurophilic or specific granule contents, or purified neutrophil elastase, we did not see a similar cytotoxic effect. The purified azurophilic granule contents retained elastolytic and nonspecific protease activity. Thus, the cytotoxic mechanism in our system is different from that reported by Smedly et al. (57), who found that elastase was cytotoxic to endothelial cells in their system. Although plasma membrane-associated neutral proteases have been implicated as an agent of injury in other in vitro systems (45), we saw no cytotoxic effect when epithelial cells were exposed to neutrophil lysates or neutroplasts. The failure to demonstrate cytotoxicity using these neutrophil-derived products may be due to instability of the toxic agent(s) or requirements for higher local concentrations.

A possible explanation for some of the inhibition of neutrophil-induced killing by antiproteases comes from our observation that neutrophil adherence was reduced in the presence of these inhibitors. Because the anti-Mol experiments suggested that decreased adherence reduces the cytotoxic effect of stimulated neutrophils, we speculate this may be a mechanism responsible for part of the protection seen with antiproteases.

Because neutrophil cationic proteins have cytotoxic effects in some experimental systems (39-43), we investigated the effect of these agents by adding to the neutrophils polyanions that would electrostatically bind to the cationic proteins. Previous reports have demonstrated that polyanions inhibit cationic protein-dependent microbicidal activity $(39,40,42)$. Both heparin and dextran sulfate reduced epithelial cell killing. Additional information, however, questioned the primary role of cationic proteins in causing cellular injury. Specifically, the contents of purified azurophilic granules (which contain the cationic proteins) did not injure the epithelial cells.

In vitro studies have demonstrated that neutrophils possess a wide variety of microbicidal armaments. Both oxygen metabolite-dependent and -independent processes have been elucidated $(43,58)$. The redundance of these protective mechanisms is demonstrated by the existence of patients with profound defects in single microbicidal systems yet these patients are able to kill many types of invading microorganisms. It should therefore not be surprising that in vitro studies of neutrophil function also reveal a variety of cytotoxic mechanisms, both oxygen metabolite dependent and independent. By extrapolating to the intact experimental animal or human, we would suspect that neutrophilinduced epithelial cell injury caused by inflammation is also likely to be multifactorial.

In summary, we have demonstrated that stimulated human neutrophils can kill isolated rat alveolar epithelial cells. The process of cellular injury did not require neutrophil-generated oxygen metabolites. Adherence of neutrophils to epithelial cells appeared to be an important component of the cytotoxic process.

\section{Acknowledgments}

The authors thank Dr. Peter A. Ward, Department of Pathology, for his advice as well as for providing laboratory space and access to scientific equipment; Dr. John T. Curnutte, Scripps Clinic and Research Foundation, La Jolla, CA, for providing neutrophil azurophilic and specific granules and for access to the neutrophils from chronic granulomatous disease patients; Dr. Una S. Ryan, University of Miami School of Medicine, for providing bovine pulmonary endothelial cells; Ms. Robin Kunkel, Department of Pathology, for performing the electron microscopy, and Mr. David Nadeau for technical assistance.

This study was supported in part by grants from the National Heart, Lung and Blood Institute (HL-31963), the National Cancer Institute (CA-39064), and a grant-in-aid from the American Heart Association with funds contributed in part by the American Heart Association of Michigan (84-1058).

\section{References}

1. Nash, G., F. D. Foley, and P. C. Langlinais. 1974. Pulmonary and interstitial edema and hyaline membranes in adult burn patients. Hum. Pathol. 5:149-161.

2. Bachofen, M., and E. R. Weibel. 1977. Alterations of the gas exchange apparatus in adult respiratory insufficiency associated with septicemia. Am. Rev. Respir. Dis. 116:589-615.

3. Taylor, A. E., and K. A. Garr, Jr. 1970. Estimation of equivalent pore radii of pulmonary capillary and alveolar membranes. Am. J. Physiol. 218:1133-1140.

4. Jacob, H. S., P. R. Craddock, D. E. Hammerschmidt, and C. F. 
Moldow. 1980. Complement-induced granulocyte aggregation: an unsuspected mechanism of disease. N. Engl. J. Med. 302:789-794.

5. Lee, C. T., A. M. Fein, M. Lippmann, H. Holtzman, P. Kimbel, and G. Weinbaum. 1981. Elastolytic activity in pulmonary lavage fluid from patients with adult respiratory distress syndrome. $N$. Engl. J. Med. 304:192-196.

6. Fantone, J. C., and P. A. Ward. 1982. Role of oxygen-derived free radicals and metabolites in leukocyte-dependent inflammatory reactions. Am. J. Pathol. 107:397-418.

7. McGuire, W. W., R. G. Spragg, A. B. Cohen, and C. G. Cochrane. 1982. Studies on the pathogenesis of the adult respiratory distress syndrome. J. Clin. Invest. 69:543-553.

8. Rinaldo, J. E., and R. M. Rodgers. 1982. Adult respiratory-distress syndrome; changing concepts of lung injury and repair. N. Engl. J. Med. 306:900-909.

9. Cochrane, C. G., R. Spragg, and S. D. Revak. 1983. Pathogenesis of the adult respiratory distress syndrome: evidence of oxidant activity in bronchoalveolar lavage fluid. J. Clin. Invest. 71:754-761.

10. Tate, R. M., and J. E. Repine. 1983. Neutrophils and the adult respiratory distress syndrome. Am. Rev. Respir. Dis. 128:552-558.

11. Zimmerman, G. A., A. D. Renzetti, and H. R. Hill. 1983. Functional and metabolic activity of granulocytes from patients with adult respiratory distress syndrome. Am. Rev. Respir. Dis. 127:290-300.

12. Thommasen, H. V., J. A. Russell, W. J. Boyko, and J. C. Hogg. 1984. Transient leucopenia associated with adult respiratory distress syndrome. Lancet. i:809-812.

13. Brigham, K. L., and B. Meyrick. 1984. Interactions of granulocytes with the lungs. Circ. Res. 54:623-635.

14. Johnson, D., and J. Travis. 1979. The oxidative inactivation of human $\alpha$-1-proteinase inhibitor. J. Biol. Chem. 254:4022-4026.

15. Shechter, Y., Y. Burstein, and A. Patchornik. 1975. Selective oxidation of methionine residues in proteins. Biochemistry. 14:44974503.

16. Crestfield, A. M., S. More, and W. H. Stein. 1963. The preparation and enzymatic hydrolysis of reduced and s-carboxylated proteins. J. Biol. Chem. 238:622-627.

17. Bergmeyer, H. U. 1955. Zur Messung von Katalase-Aktivitäten. Biochem. Z. 327:255-258.

18. Todd, R. F. III, L. M. Nadler, and S. F. Schlossman. 1981. Antigens on human monocytes identified by monoclonal antibodies. J. Immunol. 126:1435-1442.

19. Arnaout, M. A., R. F. Todd III, N. Dana, J. Melamed, S. F. Schlossman, and H. R. Colten. 1983. Inhibition of phagocytosis of complement C3- or immunoglobulin G-coated particles and of C3bi binding by monoclonal antibodies to a monocyte-granulocyte membrane glycoprotein (Mol). J. Clin. Invest. 72:171-179.

20. Todd, R. F. III, J. A. Roach, and M. A. Arnaout. 1985. The modulated expression of Mo5, a human myelomonocytic plasma membrane antigen. Blood. 65:964-973.

21. Todd, R. F. III, S. C. Meuer, P. L. Romain, and S. F. Schlossman. 1984. A monoclonal antibody that blocks class II histocompatabilityrelated immune interactions. Hum. Immunol. 10:23-40.

22. Simon, R. H., J. P. McCoy, Jt., A. E. Chu, P. D. Dehart, and I. J. Goldstein. 1986. Binding of Griffonia simplicifolia I lectin to rat pulmonary alveolar macrophages and its use in purifying type II alveolar epithelial cells. Biochim. Biophys. Acta. 885:34-42.

23. Mason, R. J., and M. C. Williams. 1976. Identification of type II alveolar cells with phosphine 3R. Am. Rev. Respir. Dis. 113:47. (Abstr.)

24. Ryan, U. S., E. Clements, D. Habliston, and J. W. Ryan. 1978 Isolation and culture of pulmonary artery endothelial cells. Tissue Cell. 10:535-554.

25. Boyüm, A. 1968. Isolation of mononuclear cells and granulocytes from human blood. Isolation of mononuclear cells by one centrifugation; and of granulocytes by combining centrifugation and sedimentation at 1g. Scand. J. Clin. Lab. Invest. 21(Suppl. 97):77-89.

26. Roos, D., A. A. Voetman, and L. J. Meerhof. 1983. Functional activity of enucleated human polymorphonuclear leukocytes. J. Cell Biol. 97:368-377.
27. Worthington Enzyme Manual. 1982. Worthington Biochemical Corp., Freehold, NJ. 100-101.

28. Bretz, U., and M. Baggiolini. 1973. Association of the alkaline phosphatase of rabbit polymorphonuclear leukocytes with the membrane of the specific granules. J. Cell Biol. 59:696-707.

29. McCord, J. M., and I. Fridovich. 1969. Superoxide dismutase. J. Biol. Chem. 244:6049-6055.

30. Ruch, W., P. H. Cooper, and M. Baggiolini. 1983. Assay of $\mathrm{H}_{2} \mathrm{O}_{2}$ production by macrophages and neutrophils with homovanillic acid and horseradish peroxidase. J. Immunol. Methods. 63:347-357.

31. Sacher, L. A., K. K. Winter, N. Sicher, and S. P. Frankel. 1955. Photometric method for estimation of elastase activity. Proc. Soc. Exp. Biol. Med. 90:323-326.

32. Lowry, O. H., N. J. Rosebrough, A. L. Farr, and R. J. Randall. 1951. Protein measurement with the Folin phenol reagent. J. Biol. Chem. 193:265-275.

33. Zar, J. H. 1974. Biostatistical Analysis. Prentiss-Hall, Inc., Englewood Cliffs, NJ. 1-620.

34. Curnutte, J. T., D. M. Whitten, and B. M. Babior. 1974. Defective superoxide production by granulocytes from patients with chronic granulomatous disease. N. Engl. J. Med. 290:593-597.

35. Sacks, T., C. F. Moldow, P. R. Craddock, T. K. Bowers, and H. S. Jacob. 1978. Oxygen radicals mediate endothelial cell damage by complement-stimulated granulocytes. J. Clin. Invest. 61:1161-1167.

36. Weiss, S. J., J. Young, A. F. LoBuglio, A. Slivka, and N. F. Nimeh. 1981. Role of hydrogen peroxide in neutrophil-mediated destruction of cultured endothelial cells. J. Clin. Invest. 68:714-721.

37. Martin, W. J. II. 1984. Neutrophils kill pulmonary endothelial cells by a hydrogen-peroxide-dependent pathway. Am. Rev. Respir. Dis. 130:209-213.

38. Varani, J., S. E. G. Fliegel, G. O. Till, R. G. Kunkel, U. S. Ryan, and P. A. Ward. 1985. Pulmonary endothelial cell killing by human neutrophils: possible involvement of hydroxyl radical. Lab. Invest. 53: 656-663.

39. Zeya, H. I., and J. K. Spitznagel. 1966. Cationic proteins of polymorphonuclear leukocyte lysosomes. J. Bacteriol. 91:755-762.

40. Clark, R. A., I. Olsson, and S. J. Klebanoff. 1976. Cytotoxicity for tumor cells of cationic proteins from human neutrophil granules. $J$. Cell Biol. 70:719-723.

41. Weiss, J., M. Victor, O. Stendhal, and P. Elsbach. 1982. Killing of gram-negative bacteria by polymorphonuclear leukocytes. J. Clin. Invest. 69:959-970.

42. Thorne, K. J. I., J. M. Norman, S. F. Haydock, D. A. Lammas, and P. H. Duffus. 1984. Antibody-dependent cell-mediated cytotoxicity against IBR-infected bovine kidney cells by ruminant neutrophils: the role of lysosomal cationic protein. Immunology. 53:275-282.

43. Spitznagel, J. K., and W. M. Shafer. 1985. Neutrophil killing of bacteria by oxygen-independent mechanisms: a historical summary. Rev. Infect Dis. 7:398-403.

44. Campbell, E. J., R. M. Senior, J. A. McDonald, and D. L. Cox. 1982. Proteolysis by neutrophils. J. Clin. Invest. 70:845-852.

45. Pontremoli, S., E. Melloni, M. Michetti, O. Sacco, B. Sparatore, F. Salamino, G. Damiani, and B. L. Horecker. 1986. Cytolytic effects of neutrophils: role for a membrane-bound neutral protease. Proc. Natl. Acad. Sci. USA. 83:1685-1689.

46. Todd, R. F. III, and M. A. Arnaout. 1986. Monoclonal antibodies that identify Mol and LFA-1, two human leukocyte membrane glycoproteins: a review. In Leukocyte Typing II. Human Myeloid and Hematopoeitic Cells. Vol. 3. E. L. Reinherz, B. F. Haynes, L. M. Nadler, and I. B. Bernstein, editors. Springer-Verlag, New York 95-108.

47. Arnaout, M. A., R. M. Hakim, R. F. Todd III, N. Dana, and H. R. Colten. 1985. Increased expression of an adhesion-promoting surface glycoprotein in the granulocytopenia of hemodialysis. $N$. Engl. J. Med. 312:457-462.

48. Harlan, J. M., P. D. Killen, L. A. Harker, G. E. Striker, and D. G. Wright. 1981. Neutrophil-mediated endothelial injury in vitro. $J$. Clin. Invest. 68:1394-1403. 
49. Suttorp, N., and L. M. Simon. 1982. Enhancement of polymorphonuclear leukocyte-mediated cytotoxicity in lung cells exposed to sustained in vitro hyperoxia. J. Clin. Invest. 70:342-350.

50. Ayars, G. H., L. C. Altman, H. Rosen, and T. Doyle. 1984. The injurious effect of neutrophils on pneumocytes in vitro. Am. Rev. Respir. Dis. 130:964-973.

51. Douglas, W. H. J., and M. E. Kaighn. 1974. Clonal isolation of differentiated rat lung cells. In Vitro (Rockville). 10:230-237.

52. Mason, R. J., and M. C. Williams. 1980. Phospholipid composition and ultrastructure of A549 cells and other cultured pulmonary epithelial cells of presumed type II cell origin. Biochim. Biophys. Acta. 617:36-50.

53. Haslett, C., L. A. Guthrie, M. M. Kopaniak, R. B. Johnston, Jr., and P. M. Henson. 1985. Modulation of multiple neutrophil functions by preparative methods or trace concentrations of bacterial lipopolysaccharide. Am. J. Pathol. 199:101-110.

54. Boogaerts, M. A., O. Yamada, H. S. Jacobs, and C. F. Moldow.
1982. Enhancement of granulocyte-endothelial cell adherence and granulocyte-induced cytoxicity by platelet release products. Proc. Natl. Acad. Sci. USA. 79:7019-7023.

55. Shasby, D. M., S. S. Shasby, and M. J. Peach. 1983. Granulocytes and phorbol myristate acetate increase permeability to albumin of cultured endothelial monolayers and isolated perfused lungs. Am. Rev. Respir. Dis. 127:72-76.

56. Diener, A. M., P. G. Beatty, H. D. Ochs, and J. M. Harlan. 1985. The role of neutrophil membrane glycoprotein 150 (GP-150) in neutrophil-mediated endothelial cell injury in vitro. J. Immunol. 135:537-543.

57. Smedly, L. A., M. G. Tonnesen, R. A. Sandhaus, C. Haslet, L. A. Guthrie, R. B. Johnston, Jr., P. B. Henson, and G. S. Worthen. 1986. Neutrophil-mediated injury to endothelial cells. J. Clin. Invest. 77:1233-1243.

58. Elsbach, P., and J. Weiss. 1983. A reevaluation of the roles of the $\mathrm{O}_{2}$-dependent and $\mathrm{O}_{2}$-independent microbicidal systems of phagocytes. Rev. Inf. Dis. 5:843-853. 